\title{
Preface to the updated edition
}

THIS REVISION was completed in January 2016 to take account of changes in the European scene since the book was completed in June 2013. In addition to the colleagues and friends who assisted me greatly with the first edition, I would like to thank John Nugée, Niels Thygesen, John Mourmouras, Athanasios Orphanides and Otmar Issing for their helpful comments on the revised text. Today's nineteen member states of the economic and monetary union have, it is true, taken some useful and relevant steps towards repairing some of the flaws in the single currency project laid bare by years of crisis, not least the move towards euro area-wide banking supervision with the European Central Bank as the centrepiece. In view of the rising headwinds against more political integration, however, politicians are engaged in a race against time to complete necessary strengthening measures before the next bout of economic unrest surfaces and confronts European governments with a still graver challenge. Despite the undoubted advances in understanding the problems faced by the euro area and taking some sensible structural measures towards resolving them, Europe remains ensnared in a deadlock that is all the more 
debilitating for having been brought about, above all, by the continent's own shortcomings.

\author{
David Marsh \\ Wimbledon, January 2016
}

